\title{
Final Report on ITER Task Agreement 81-18
}

\author{
Brad J. Merrill
}

February 2008

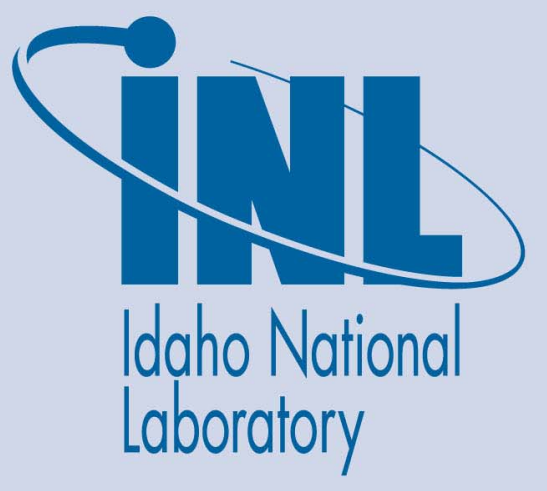

The INL is a U.S. Department of Energy National Laboratory operated by Battelle Energy Alliance 


\title{
Final Report on ITER Task Agreement 81-18
}

\author{
Brad J. Merrill
}

February 2008

Idaho National Laboratory

Idaho Falls, Idaho 83415

Prepared for the

U.S. Department of Energy Office of Science

Under DOE Idaho Operations Office

Contract DE-AC07-05ID14517 


\section{ABSTRACT}

During 2007, the US International Thermonuclear Experimental Reactor (ITER) Project Office (USIPO) entered into a Task Agreement (TA) with the ITER International Organization (IO) to conduct Research and Development activity and/or Design activity in the area of Safety Analyses. There were four tasks within this TA, which were to provide the ITER IO with: 1) Quality Assurance (QA) documentation for the MELCOR 1.8.2 Fusion code, 2) a pedigreed version of MELCOR 1.8.2, 3) assistance in MELCOR input deck development and accident analyses, and 4) support and assistance in the operation of the MELCOR 1.8.2. This report, which is the final report for this agreement, documents the completion of the work scope under this ITER TA, designated as TA 81-18. 


\section{ACRONYMS}

\begin{tabular}{|c|c|}
\hline AAS & Accident Analysis Specification \\
\hline EA & Enterprise Architecture \\
\hline EDMS & Electronic Document Management System at INL \\
\hline EU & European Union \\
\hline EVITA & European Vacuum Impingement Test Apparatus \\
\hline FRA & French Regulatory Authorities \\
\hline GSSR & Generic Site Safety Report \\
\hline HTO & Tritiated Water $\left(\mathrm{H}_{2} \mathrm{O}\right)$ \\
\hline IDM & ITER Document Management \\
\hline INL & Idaho National Laboratory \\
\hline $\mathrm{IO}$ & International Organization \\
\hline ITA & ITER Task Agreement \\
\hline ITER & International Thermonuclear Experimental Reactor \\
\hline QA & Quality Assurance \\
\hline RPrS & Report Preliminary on Safety \\
\hline SADL & Safety Analysis Data List \\
\hline SCMP & Software Configuration Management Plan \\
\hline SQAP & Software Quality Assurance Plan \\
\hline TA & Task Agreement \\
\hline VV & Vacuum Vessel \\
\hline
\end{tabular}




\section{CONTENTS}

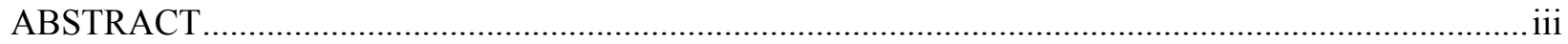

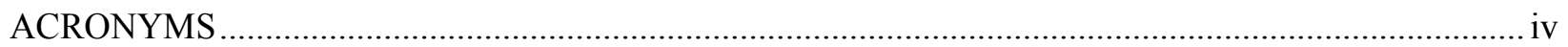

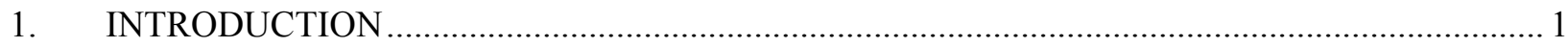

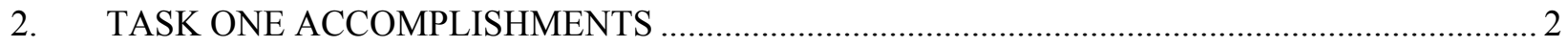

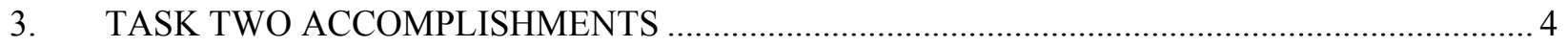

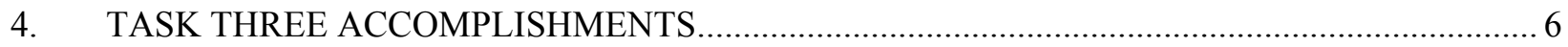

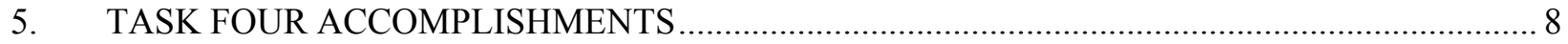

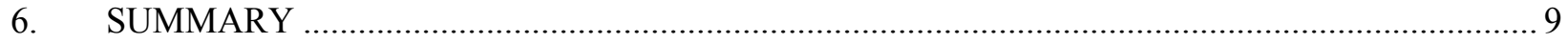

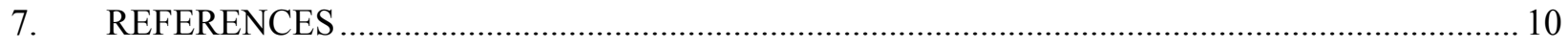

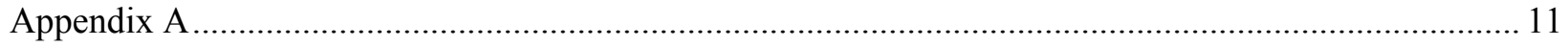




\section{Final Report on ITER Task Agreement 81-18 \\ 1. INTRODUCTION}

On February $28^{\text {th }}$ of 2007, the US International Thermonuclear Experimental Reactor (ITER) Project Office (USIPO) entered into a Task Agreement (TA) with the ITER International Organization (IO) to conduct Research and Development activity and/or Design activity in the area of Safety Analyses [Sau07]. The title of this ITER TA (ITA 81-18) is: "Support and Assistance for MELCOR Quality Assurance and Safety Analysis". There are four tasks within this TA, which were to:

1) Provide the ITER IO citable references for the Software Development Plan, Software Management Plan, and any validation studies and peer reviews for the MELCOR 1.8.2 Fusion code. This includes references for the basic fission version of the code and for the modifications that have been made to MELCOR that allow application to a fusion device,

2) Provide the ITER IO with a pedigreed version of MELCOR 1.8.2 that complies with QA documentation and requirements for a Linux system at the INL and MELCOR 1.8.2 executables that have been compiled on computer systems that use the Linux and Windows XP operating systems,

3) Provide the ITER IO with assistance in MELCOR input deck development and accident analyses for ITER's "Rapport Préliminaire de Sûreté" (Report

Preliminary on Safety - RPrS), and

4) Provide support and assistance in operation of the codes.

This report, which is the final report for this agreement, documents the completion of the work scope under ITER TA 81-18. Descriptions of the accomplishments under TA 81-18 are contained within the following sections of this report, with each section discussing one of the tasks of this ITA. Section 6 summarizes the work of this ITA. Finally, Appendix A contains a copy of the Task Agreement Tracking Sheet for this ITA with dates for when key deliverables were sent to the ITER IO. 


\section{TASK ONE ACCOMPLISHMENTS}

The purpose of this task was to provide the ITER IO citable references for the Software Development Plan, Software Management Plan, and any validation studies and peer reviews for the MELCOR 1.8.2 Fusion code. This includes references for the basic fission version of the code and for the modifications that have been made to MELCOR 1.8.2 that allow application to fusion devices. The work under Task 1 was completed during the fourth quarter of fiscal year (FY) 2007.

The work for this task included:

1) Placing the version of the MELCOR code being used by ITER for the RPrS in the Idaho National Laboratory (INL) Software Quality Assurance (QA) system,

2) Documenting recent changes to the MELCOR code, in particular the HTO transport model, and

3) Placing QA documentation in the ITER Document Management (IDM) system.

The pedigreed version of the MELCOR 1.8.2 code used for RPrS analyses was entered into the INL Enterprise Architecture (EA) Software QA system as a Quality Level 1 Safety Analysis Legacy Code. An INL Software Quality Assurance Plan (SQAP) and INL Software Configuration Management Plan (SCMP) were written, reviewed and entered into the INL EA system. The SQAP is entitled: "MELCOR Software Management for ITER: Software Quality Assurance (SQA) Plan" [Mer07b]. The SCMP is entitled: "MELCOR Software Management for ITER: Software Configuration Management Plan" [Mer07c]. All supporting documents relating to fusion: change documents, requirements and review documents, validation documents, and verification documents were obtained and entered into the INL Electronic Document Management System (EDMS). This amounted to 23 documents, most of which had to be converted from hardcopy to electronic format. In addition, more than 30 fission related supporting QA documents where obtained and converted into electronic format. All of these documents now reside on IDM under the MELCOR folder established at the following link:

https://users.iter.org/users/idm?folder_path=folderTree/Project_Integration_Administratio n_Services/Safety/Safety Assessment/Safety Codes Documentation

In this MELCOR folder are the following five subfolders that contain this documentation:

1) MELCOR executables 
2) MELCOR Fusion Modifications

3) MELCOR Fusion Validation

4) MELCOR Fission Documents, and

5) INL QA Documents.

Two additional documents were developed under this task. The first document, published as an INL External Report entitled: "Recent Updates to the MELCOR 1.8.2 Code for ITER Applications" [Mer07a], documents recent changes made to the MELCOR 1.8.2 computer code for application to the ITER [Moo07]. Four areas of code development were documented in [Moo07, which are:

1) The addition of a model for transporting tritiated water (HTO),

2) Updating of the material oxidation correlations to match those specified in the latest version of the ITER Safety Analysis Data List (SADL).

3) Modification to an aerosol transport subroutine that specified the nominal aerosol density internally with one that now allows the user to specify this density through user input, and

4) An error that existed in an air condensation subroutine of previous versions of this modified MELCOR code was corrected.

The second document, also published as an INL External Report entitled: "Benchmarking MELCOR 1.8.2 for ITER Against Recent EVITA Results" [Mer07d], documents a validation study for the MELCOR 1.8.2 computer code against data from the European Vacuum Impingement Test Apparatus (EVITA) facility located in Cadarache, France. EVITA Test Series 7 was used for this study to verify MELCOR's ability to predict pressures, temperatures, cryoplate ice mass, and vacuum vessel (VV) condensate mass for test conditions in EVITA that included injections of steam, nitrogen, and water in to the EVITA VV after the VV walls had been heated to $165^{\circ} \mathrm{C}$ and the cryoplate had been cooled to $-193{ }^{\circ} \mathrm{C}$. 


\section{TASK TWO ACCOMPLISHMENTS}

The purpose of Task 2 under this ITA was to provide the ITER IO with a pedigreed version of MELCOR 1.8.2 that complies with QA documentation and requirements, developed on a Linux system at the INL, and to supply the ITER IO with pedigreed MELCOR 1.8.2 executables that can execute on both Linux and Windows XP operating systems. The work under this ITA task was completed during the third quarter of FY 2007.

The work under this task included:

1) Developing a pedigreed version of the MELCOR 1.8.2 for use by ITER to perform the RPrS calculations,

2) Documenting the pedigree process, and

3) Placing executables of the pedigreed version of MELCOR 1.8.2 for Linux and Windows XP operating systems on IDM, along with a user installation guide for these executables.

The pedigree process for MELCOR 1.8.2 Fusion code entailed the following:

1) A line by line review of the FORTRAN coding changes made to the MELCOR 1.8.2 code as called out in the change documents described in the previous section,

2) Testing of the pedigreed version against a set of test problems that include three MELCOR accident analyses reported in the ITER-FEAT Generic Site Safety Report (GSSR) [GSS04], four MELCOR 1.8.2 Fusion development test problems as called out in the change documents, and one demonstration problem included with the original distribution files for the MELCOR 1.8.2 code,

3) Comparing the pedigreed version results for the eight test problems mentioned above against results from GSSR analyses performed with a pre-1995 version of MELCOR 1.8.2 Fusion as supplied by the ITER IO, the results documented in the change reports, and the MELCOR 1.8.2 results obtained during the installation process of MELCOR 1.8.2 at the INL in 1994, and

4) Documenting the comparison in a Pedigree/Non-regression Analysis report to be included in the MELCOR 1.8.2 Fusion QA documentation. 
An external INL report was issued documenting the MELCOR 1.8.2 pedigree process, entitled: "Pedigree Analysis of the MELCOR 1.8.2 Code to be Used for ITER's Report Preliminary on Safety" [Moo07]. Pedigreed versions of the MELCOR 1.8.2 Fusion code compiled on both 64 and 32 bit Linux and Windows XP operating systems at the INL were uploaded to the IDM system into the MELCOR executables folder. A MELCOR Executable Installation Guide was written for these executables and placed in the IDM MELCOR subfolder designated as: "Reference input files for installation validation". MELCOR plot files for installation test problems, generated on the same INL Linux system that the pedigreed version of MELCOR resides, were uploaded into IDM to the same subfolder as the installation guide.

These files are to be the basis for determining if the executables are operating properly by those users installing these executables on their computer systems. It was left to the person installing these executables to document a successful installation process prior to the application of these executables to RPrS analyses. 


\section{TASK THREE ACCOMPLISHMENTS}

The purpose of Task 3 was to provide the ITER IO with assistance in MELCOR input deck development and accident analyses for the RPrS. The work under Task 3 was completed during the second quarter of FY 2008.

The work under this task included the following two activities:

1) Verification of MELCOR input decks developed for use in ITER RPrS calculations, and

2) Perform and document the analyses of three accident scenarios selected by the ITER IO for inclusion in the ITER RPrS.

We are providing an independent line-by-line review of the seven MELCOR input decks that were developed by the ITER IO for use in ITER RPrS analyses, to confirm that these decks conform to ITER safety analysis requirements. An INL External Report was written that documents this activity, entitled: "Verification of MELCOR Input Decks Used in ITER RPrS Analyses" [Moo08]. The verification process for each computer deck consisted of five tasks, which are as follows:

1) Verify that each of the control volume (CV) used to represent an ITER component volume such as the plasma chamber, suppression system piping, etc, has a volume vs. height table that is consistent with that given in [SAD07],

2) Verify that the each flow path (FP) connecting the CVs in a given sub-model have the correct lengths, flow areas, and hydraulic diameters as determined from information given in [SAD07],

3) Verify that each heat structure used in a given sub-model (walls, pipes and materials) represents the structure as described in [SAD07],

4) Ensure that the opening of valves used to simulate breaks in the piping and walls occur at the correct time or pressure differential. Make sure that the break area and location of these simulated breaks are consistent with those described in the [AAS07], and

5) Ensure that the control logic used to simulate leaks in various ITER confinement building rooms is programmed correctly to give leak rates as specified in [SAD07] and [AAS07]. 
Under ITA 81-18, the US was tasked with performing analyses for ITER's "Rapport Préliminaire de Sûreté" (Report Preliminary on Safety - RPrS) with the pedigreed version of the MELCOR 1.8.2 code [Moo07]. These analyses were for the following three accidents:

1) A coolant leak from ITER first wall (FW)/blanket (BL) primary heat transport system (PHTS) in the port cell of the ITER confinement building,

2) Ingress of water from ITER's FW/BL PHTS into the ITER cryostat, and

3) Ingress of water from ITER's FW/BL PHTS and helium ITER's toroidal field (TF) magnets into the cryostat of the ITER device.

Analyses of these accidents were completed and documented in an external INL technical report entitled: "MELCOR 1.8.2 Analyses in Support of ITER's RPrS" [Mer08]. The reporting format for the analyses followed that of [GSS04], as requested by the ITER IO. Accordingly, for each accident the following discussions were included in this external INL report:

1) Identify the causes of the accident and describe how the accident proceeds,

2) Present the method used in analyzing the accident,

3) Describe the transient analysis results for the base accident case,

4) Describe the transient analysis results for any parameter studies for this accident,

5) Present an evaluation of radiological releases,

6) Present an evaluation of parameter study radiological releases,

7) Discuss uncertainties in obtained results, and

8) Close with a results summary.

The reports written under this task were placed in IDM as QA documents. 


\section{TASK FOUR ACCOMPLISHMENTS}

The purpose of Task 4 was to provide support and assistance to the ITER IO in operation of the MELCOR code. Under this task, the INL FSP supplied on-call support to the ITER IO and to analysts in the European Union (EU) used the MELCOR code for RPrS analyses. This support continued on through the RPrS submittal process to include the defense of MELCOR predictions to French Regulatory Authorities (FRA). The activities under this task included:

1) Assisting the ITER IO in developing a QA strategy for MELCOR 1.8.2,

2) Providing input to a Safety Dossier for MELCOR 1.8.2,

3) Reviewing of RPrS Volumes that contained accident consequence analyses,

4) Assisting EU analysts in obtaining permission for the US Nuclear Regulatory Commission (NRC) to use the MELCOR 1.8.2 code developed for fusion application, and

5) Assisting the ITER IO in responding to FRA questions on MELCOR results to RPrS accident analyses.

Because the primary purpose of this task was to provide on time assistance to the ITER IO, this task was considered to be complete when this ITA concluded. 


\section{SUMMARY}

During this ITA, seven reports were generated, $\sim 8150$ lines of FORTRAN coding where checked for consistency to theory documentation and verified to be executing correctly, $\sim 52,000$ lines of MELCOR RPrS input were checked for consistency with ITER accident analysis requirements, more than 31 MELCOR analyses were performed and documented (including 12 test problems, 10 validation problems, and $9 \mathrm{RPrS}$ applications), and several volumes of the RPrS were reviewed. The milestones for this ITA were met. However, some of the milestones were not completed on schedule, due in part to the unforeseen time requirements for placing MELCOR in the INL QA system and for the RPrS MELCOR input deck review and revision process.

The INL FSP would like to conclude that this ITA has been successfully completed. However it is our suggestion that a follow-on task agreement be negotiated to provide the ITER IO with support and assistance regarding MELCOR analyses and RPrS review. In addition, as was discussed in [Moo07], the decision to use an outdated version of MELCOR for RPrS applications stemmed primarily from the ease with which this version could be QA'ed. It is proposed that the fusion specific models now in MELCOR 1.8.2 be added to the latest version of MELCOR (version 1.8.6), and the QA process now in place for MELCOR 1.8.2 be extended to include this conversion work for MELCOR 1.8.6. It is anticipated that during the RPrS review process that the FRA will ask for comparisons between these two versions of the MELCOR code. 


\section{REFERENCES}

[AAS07] Reyes, S., et al., “Accident Analysis Specifications (AAS),” ITER Document, ITER D 258QGE, v2.5, August (2007).

[GSS04] “Generic Site Safety Report,” ITER Report, ITER G 84 RI 6 R0.2, July (2004).

[Mer07a] Merrill, B. J., "Recent Updates to the MELCOR 1.8.2 Code for ITER Applications," Idaho National Laboratory Report, INL/EXT-07-12493, May (2007).

[Mer07b] Merrill, B. J., “MELCOR Software Management for ITER: Software Quality Assurance (SQA) Plan," Idaho National Laboratory Report, PLN-2591, September (2007).

[Mer07c] Merrill, B. J., "MELCOR Software Management for ITER: Software Configuration Management Plan," Idaho National Laboratory Report, PLN-2626, September (2007).

[Mer07d] Merrill, B. J., "Benchmarking MELCOR 1.8.2 for ITER Against Recent EVITA Results, "Idaho National Laboratory Report, INL/EXT-07-13521, November (2007).

[Mer08] Merrill, B. J., “MELCOR 1.8.2 Analyses in Support of ITER's RPrS," Idaho National Laboratory Report, INL/EXT-08-13668, January (2008).

[Moo07] Moore, R. L., "Pedigree Analysis of the MELCOR 1.8.2 Code to be Used for ITER's Report Preliminary on Safety," Idaho National Laboratory Report, INL/EXT-0712856, June (2007).

[Moo08] Moore, R. L., "Verification of MELCOR Input Decks Used in ITER RPrS Analyses," Idaho National Laboratory Report, INL/EXT-07-13305, January (2008).

[SAD07] Topilski, L., et al., "Safety Analysis Data List," ITER Report, ITER D 24LSAE, version 5.2, May 29 (2007).

[Sau07] N. Sauthoff, "Support and assistance for MELCOR Quality Assurance and Safety Analyses," ITER Task Agreement, ITA 81-18, TN C81TD30FU, June 3 (2007). 


\section{Appendix A}

Tracking Sheet to Monitor the Progress of the Task 
Task Agreement Tracking Sheet-Task Number and Task Title: ITA 81-18 Support and assistance for MELCOR Quality Assurance and Safety Analyses

\begin{tabular}{|c|c|c|c|c|c|c|c|}
\hline $\begin{array}{l}\text { Subtask } \\
\text { description }\end{array}$ & $\begin{array}{l}\text { Schedule } \\
\text { description } \\
\text { of the mile } \\
\text { stone }\end{array}$ & $\begin{array}{l}\text { Schedule } \\
\text { milestone } \\
\text { target } \\
\text { date }\end{array}$ & $\begin{array}{l}\text { Schedule } \\
\text { milestone } \\
\text { achieved } \\
\text { date }\end{array}$ & $\begin{array}{l}\text { Deliverables } \\
\text { description }\end{array}$ & $\begin{array}{l}\text { Deliverabl } \\
\text { es target } \\
\text { delivery } \\
\text { date }\end{array}$ & $\begin{array}{l}\text { Deliverables } \\
\text { actual } \\
\text { delivery date }\end{array}$ & $\begin{array}{l}\text { Credit agreed to be } \\
\text { allocated to PT/DA in } \\
\text { kIUA }\end{array}$ \\
\hline \multirow{3}{*}{$\begin{array}{l}\text { MELCOR } \\
\text { QA } \\
\text { documentati } \\
\text { on }\end{array}$} & QA docs. & $30 / 9 / 07$ & $30 / 9 / 07$ & QA docs. & $30 / 9 / 07$ & $30 / 9 / 07$ & 0.075 \\
\hline & & & & & & & \\
\hline & & & & & & & \\
\hline \multirow{2}{*}{$\begin{array}{l}\text { Pedigreed } \\
\text { MELCOR } \\
1.8 .2\end{array}$} & $\begin{array}{l}\text { Code } \\
\text { version }\end{array}$ & $31 / 3 / 07$ & $25 / 5 / 07$ & $\begin{array}{l}\text { Code } \\
\text { version }\end{array}$ & $31 / 3 / 07$ & $25 / 5 / 07$ & 0.075 \\
\hline & Installation & $30 / 4 / 07$ & $29 / 6 / 07$ & Installation & $30 / 4 / 07$ & $29 / 6 / 07$ & 0.03 \\
\hline \multirow{2}{*}{$\begin{array}{l}\text { Input decks } \\
\text { and accident } \\
\text { analyses }\end{array}$} & $\begin{array}{l}\text { Update } \\
\text { models }\end{array}$ & $31 / 3 / 07$ & $27 / 11 / 07$ & $\begin{array}{l}\text { Update } \\
\text { models }\end{array}$ & $31 / 3 / 07$ & $30 / 01 / 08$ & 0.045 \\
\hline & $\begin{array}{l}\text { Analyses } \\
\mathrm{rpt}\end{array}$ & $31 / 10 / 07$ & $18 / 10 / 07$ & Analyses rpt & $31 / 10 / 07$ & 07/01/08 & 0.045 \\
\hline \multirow{2}{*}{$\begin{array}{l}\text { Support and } \\
\text { assistance }\end{array}$} & Support & $31 / 12 / 07$ & $23 / 01 / 08$ & Support & $31 / 12 / 07$ & $29 / 02 / 08$ & 0.03 \\
\hline & & & & Final report & $29 / 2 / 08$ & $29 / 2 / 08$ & \\
\hline Sum total & & & & & & & 0.3 \\
\hline
\end{tabular}

